PLPB : Pendidikan Lingkungan dan Pembangunan Berkelanjutan

DOI : http://doi.org/10.21009/PLPB.211.01

DOI : 10.21009/PLPB

\title{
TANGGUNG JAWAB LINGKUNGAN DAN PERSEPSI ANCAMAN EKOLOGI TERHADAP PERILAKU PRO- LINGKUNGAN KARYAWAN PERUSAHAAN DI DAS CITARUM KECAMATAN BABAKANCIKAO KABUPATEN PURWAKARTA PROVINSI JAWA BARAT
}

\author{
Rita Istiana $^{1}$, Sutanto ${ }^{1}$, Rita Retnowati ${ }^{1}$, Anang Wisnu ${ }^{2}$ \\ ${ }^{1}$ Program studi Managemen Lingkungan Universitas Pakuan. \\ ${ }^{2}$ Mahasiswa Program Magister Program Studi Managemen Lingkungan Universitas Pakuan \\ e-mail: rita_istiana@unpak.ac.id
}

\begin{abstract}
This study aims to measure the relationship between corporate environmental responsibility and the perception of ecological threats to the pro-environmental behavior of company employees. It was found that the environmental responsibility of the company had an effect on the pro-environment behavior of employees by $20.1 \%$, which means that the role of the company to make rules or norms of pro-environment behavior was still very low. The perception of ecological threats has an effect on the pro-environment behavior of employees by $33.7 \%$, this explains that employees' knowledge of ecological threats is low and has not been able to provide awareness of the company's environmental sustainability. The corporate environmental responsibility and the perception of ecological threats affect the pro-environment behavior of the company's employees by $34.3 \%$. These results can explain that the role of companies to educate their employees and the application of environmental preservation rules and norms needs to be further improved.
\end{abstract}

\section{Keywords : Pro-Environment, Environmental responsibility, Ecology.}

\section{ABSTRAK}

Penelitian ini bertujuan untuk mengukur hubungan antara tanggung jawab lingkungan perusahaan dan persepsi ancaman ekologi terhadap perilaku pro-lingkungan karyawan perusahaan, Penelitian menggunakan metode survey dengan memberikan kuisoner kepada 332 orang karyawan perusahaan di Kecamatan Babakancikao Kabupaten Purwakarta Jawa Barat, yang berada tepat di tepi sungai Citarum. Ditemukan bahwa tanggung jawab lingkungan perusahaan memberikan pengaruh terhadap perilaku pro-lingkungan karyawan sebesar 20,1\%, yang berarti menggambarkan bahwa peran perusahaan untuk membuat aturan atau norma perilaku pro-lingkungan masih sangat minim. Persepsi ancaman ekologi memberikan pengaruh terhadap perilaku pro-lingkungan karyawan sebesar 33,7\%, hal ini menjelaskan bahwa pengetahuan karyawan tentang ancaman ekologi rendah dan belum mampu memberikan kesadaran terhadap kelestarian lingkungan perusahaan. Adapun secara bersama-sama tanggung jawab lingkungan perusahaan dan persepsi ancaman ekologi mempengaruhi perilaku pro-

\begin{tabular}{|l|l|l|l|}
\hline Volume XXI & Nomor 1 & Maret 2020 & e-ISSN : 2580-9199 \\
\hline
\end{tabular}


lingkungan karyawan perusahaan sebesar 34,3\%. Hasil tersebut dapat menjelaskan bahwa peran perusahaan untuk melakukan edukasi kepada karyawannya dan penerapan aturan serta norma-norma pelestarian lingkungan perlu semakin ditingkatkan.

Kata kunci : Pro-Lingkungan, Tanggung jawab lingkungan, Ekologi.

\section{PENDAHULUAN}

Sungai Citarum di Jawa Barat, memiliki peran yang penting dalam mendukung kehidupan masyarakat di sepanjang Daerah Aliran Sungai (DAS. Peran tersebut semakin hilang karena disebabkan oleh pencemaran yang dilakukan baik dari sampah rumah tangga maupun limbah dari industri. Secara umum, penyebab pencemaran sungai Citarum diidentifikasikan berasal dari perilaku manusia yang tinggal dan beraktifitas di sekitar bantaran sungai. Aktifitas tersebut dapat dikelompokan pada aktifitas rumah tangga, serta aktifitas manusia dalam lingkup industri.

Tercatat terdapat kurang lebih 2.700 perusahaan berskala sedang dan besar, membuang limbah industrinya di sungai Citarum. Hal ini menyebabkan terjadinya pencemaran sungai. Balai Besar Pengawasan Obat dan Makanan (BBPOM) Bandung melakukan penelitian terhadap ikan dan air Citarum, ditemukan berbagai zat berbahaya seperti merkuri, coliform, besi, mangan, timbal, sulfur dan klor (Saputro, 2018).

Pembuangan limbah industri langsung ke sungai disebabkan oleh perilaku karyawan industri yang berada disepanjang sungai. Perilaku karyawan itu juga sangat dipengaruhi oleh kebijakan, aturan atau norma-norma diperusahaan itu. Perusahaan yang memiliki Corporate EnvironmentalResponsibility yang baik, akan merangsang karyawannya untuk berperilaku pro-lingkungan (Ruepert, et.al, 2017).

Upaya menumbuhkan perilaku prolingkungan harus dilakukan dengan menggunakan strategi atau cara yang bertanggung jawab, serta di kampanyekan (Pothitou, et. al., 2016). Sebuah perusahaan yang membuat kebijakan yang berorientasi kepada kepentingan pelestarian lingkungan, harus memberikan informasi atau melakukan sosialisasi kepada seluruh karyawan agar seluruh karyawannya memahami dan dapat mengimplementasikan kebijakan perusahaan.

Pencemaran yang terjadi di DAS Citarum, secara nyata akan merusak ekologi disepanjang DAS Citarum. Kerusakan ekologi yang dimaksud yaitu antara lain : Kepunahan spesies, Polusi air dan udara, krisis air, berkurangnya sumber daya alam, deforestrasi, dan degradasi tanah. Menurut Schmitt, et.al., (2018) dalam penelitiannya menemukan bahwa persepsi atau pemahaman tentang ancaman ekologi mempengaruhi secara signifikan terhadap perilaku pro-lingkungan. Hal ini memberikan gambaran kepada bahwa pengetahuan atau persepsi ancaman ekologi dapat menggugah atau mendorong masyarakat untuk memiliki perilaku prolingkungan yang baik.

Perilaku pro-lingkungan adalah tindakan-tindakan yang pro-sosial dengan tujuan untuk meningkatkan kesehatan dan kesejahteraan orang lain, yang hidup pada masa sekarang dan masa yang akan datang. Perilaku pro-lingkungan juga di artikan sebagai sebuah sikap atau perilaku sukarela yang tidak dibayar, dari perseorangan dalam menjaga kelestarian lingkungan (Macintyre, \& García, 2012). Kesadaran untuk berpartisipasi dalam menjaga kelestarian lingkungan yang dilakukan secara kolektif dalam suatu kelompok masyarakat, memberikan dampak yang

\begin{tabular}{|c|c|c|c|}
\hline Volume XXI & Nomor 1 & Maret 2020 & e-ISSN : 2580-9199 \\
\hline
\end{tabular}


singnifikan terhadap pelestarian lingkungan dimana mereka tinggal.

Faktor-faktor yang mem-pengaruhi perilaku pro-lingkungan menurut Truelove \& Gillis,(2018) antara lain: sikap individu terhadap lingkungan, kepedulian individu terhadap lingkungan, dan identitas lingkungan serta orientasi nilai biosfer. Perilaku pro-lingkungan merupakan sebuah tindakan yang secara sengaja dilakukan oleh seseorang untuk melindungi kelestarian lingkungan, dan tindakan tersebut dapat di ukur.

Sesuai dengan penjelasan tersebut, dapat di definisikan bahwa perilaku prolingkungan karyawan adalah tindakan nyata individu karyawan perusahaan dalam menjaga kelestarian lingkungan dan melindungi sumber daya alam yang tersedia. Tindakan nyata individu tersebut dapat dilihat melalui beberapa indikator, diantaranya adalah: tindakan melestarikan lingkungan; menggunakan transportasi yang ramah lingkungan; berperilaku hemat energy; mengelola sampah; menghindari konsumerisme, dan mencegah timbulnya limbah.

\section{Corporate}

Environmental

Responsibility (CER) merupakan teori yang menjelaskan tentang hubungan antara perusahaan dengan lingkungannya. Hal tersebut menjelaskan tentang kewajiban pembuat keputusan perusahaan untuk bertanggung jawab atas tindakan yang dilakukan yang bertujuan untuk melindungi dan meningkatkan kelestarian lingkungan dengan tetap memperhatikan kepentingan perusahaan (Holtbrügge \& Dögl, 2012). CER atau tanggung jawab lingkungan perusahaan adalah merupakan konsep dasar untuk mengukur Corporate Social Responsibility (CSR), yaitu bentuk tanggung jawab perusahaan untuk menjaga kelestarian lingkungannya. Menurut Tkalac \& Sin, (2018), tanggung jawab lingkungan perusahaan sangat dipengaruhi oleh merek atau reputasi perusahaan tersebut. Perusahaan yang memiliki reputasi yang baik, akan memiliki tingkat kepedulian yang tinggi terhadap kelestarian lingkungan.

Menurut Mukherjee \& Duppati, (2018), CER adalah kepedulian dari perusahaan untuk turut serta menjaga kelestarian lingkungan. Kepedulian perusahaan di wujudkan dalam kewajiban yang harus dilakukan oleh perusahaan untuk menyisihkan keuntungan (laba) perusahaan yang digunakan untuk mendukung setiap usaha untuk menjaga kelestarian lingkungan tersebut. Dengan memperhatikan beberapa penjelasan tentang pengertian $C E R$, maka dapat dibuat kesimpulan bahwa tanggung jawab lingkungan perusahan adalah segala usaha yang direncanakan, dilakukan serta dikontrol/dievaluasi oleh perusahaan untuk memelihara dan menjamin keberlanjutan atau kelestarian lingkungan hidup. Hal tersebut dilakukan dengan indikator : partisipasi langsung dalam pelestarian lingkungan, manajemen hijau dan kontrol manajemen, dan pencegahan terhadap kerusakan lingkungan.

Ecological Threat atau persepsi ancaman ekologi sangat berhubungan erat dengan tingkat kesejahteraan hidup. Penelitian Schmitt et.al., (2018), menyimpulkan bahwa terdapat hubungan positif antara ancaman ekologi dengan kesejahteraan, hal tersebut dapat di jelaskan bahwa semakin tinggi tingkat kesejahteraan, maka semakin tinggi ancaman terhadap ekologi yang disebabkan. Hal yang perlu dipertimbangkan akibat resiko ekologi yang disebabkan karena empat fenomena alam (erosi, sedimentasi, diapirisme lumpur dan invasi dari spesies tertentu) dan juga oleh perilaku manusia yang menyebabkan polusi dan perubahan penggunaan lahan (Yanes, et.al., 2017).

Berdasarkan penjelasan di atas maka dapat disimpulkan bahwa persepsi ancaman ekologi adalah pandangan tentang kerusakan ekologi dan penyebabnya, yang dipengaruhi oleh perilaku pro-lingkungan.

\begin{tabular}{|l|l|l|l|}
\hline Volume XXI & Nomor 1 & Maret 2020 & e-ISSN : 2580-9199 \\
\hline
\end{tabular}


Hal tersebut diketahui dengan indikator : pandangan tentang kerusakan lingkungan, tanggapan tentang global warming, pandangan tentang menurunnya biodiversity, penafsiran tentang rendahnya daya dukung lingkungan terhadap kehidupan mahkluk hidup, dan pengamatan tentang krisis energi.

Kebaruan dari penelitian ini adalah informasi hasil penelitian ini yang berisi tentang multifaktor pendukung perilaku pro-lingkungan karyawan pabrik di bantaran DAS Citarum dapat digunakan sebagai masukan bagi pihak terkait seperti pimpinan perusahaan, Dinas Perindustrian, Badan Pengelola Lingkungan Hidup Daerah (BPLHD) Provinsi Jawa Barat. Selain itu dari informasi yang diperoleh dapat dijadikan acuan kerja tindak lanjut bagi perusahaan untuk memberi pelatihan bagi karyawan guna meningkatkan perilaku prolingkungan karyawan yang pada akhirnya dapat berperan dalam meningkatkan kualitas DAS Citarum.

\section{METODOLOGI}

\section{Tempat dan waktu penelitian}

Penelitian ini dilakukan pada karyawan perusahaan yang berada di bantaran DAS Citarum. Perusahaan yang dipilih adalah PT. IBR dan PT.SSM yang merupakan pabrik terbesar di daerah tersebut, dan terletak tepat disepanjang sungai Citarum. Kedua perusahaan tersebut berada di Kecamatan Babakancikao Kabupaten Purwakarta Provinsi Jawa Barat.

\section{Jumlah sampel}

Responden terpilih dalam penelitian ini adalah karyawan dari kedua perusahaan tersebut yang bertempat tinggal di sekitar bantaran Sungai Citarum Kecamatan Babakancikao Kabupaten Purwakarta. Pengambilan sampel menggunakan teknik Proporsional Random Sampling, dengan memperhatikan bahwa jumlah karyawan masing-masing perusahaan yang berbeda.
Total responden dalam penelitian adalah 332 orang.

\section{HASIL DAN PEMBAHASAN}

1. Hubungan antara Tanggung Jawab Lingkungan Perusahaan $\left(\mathrm{X}_{1}\right)$ dengan Perilaku Pro-Lingkungan Karyawan (Y).

Dari uji regresi sederhana diperoleh persamaan $\hat{\mathrm{Y}}_{1}=0,275 \mathrm{X}_{1}+80,144$ dengan nilai korelasi $\left(\mathrm{r}_{\mathrm{y} 1}\right)$ sebesar 0,448 yang mengartikan bahwa terdapat hubungan signifikan antara variabel tanggung jawab lingkungan perusahaan terhadap perilaku pro-lingkungan karyawan perusahaan. Besar nilai koefisien determinasi $\left(\mathrm{r}_{\mathrm{y} 1}^{2}\right)=$ 0,201, hal tersebut menyimpulkan bahwa variabel tanggung jawab mempengaruhi sebesar $20,1 \%$ terhadap perilaku prolingkungan karyawan perusahaan, sedang sisanya berasal dari variabel lain yang tidak diteliti. Gambar 1 memperlihatkan plot/alur hubungan antara tanggung jawa lingkungan perusahaan terhadap perilaku prolingkungan karyawan perusahaan

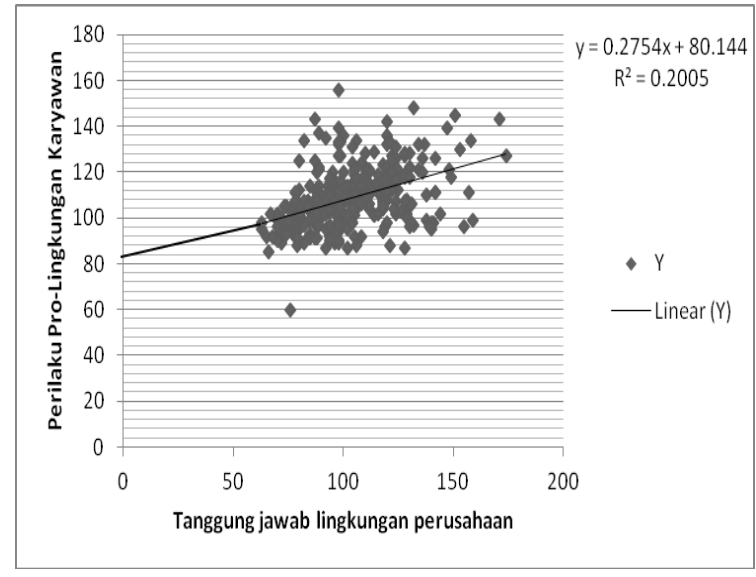

Gambar 1. Alur antara perilaku pro lingkungan karyawan terhadap tanggung jawab lingkungan perusahaan

\begin{tabular}{|l|l|l|l|}
\hline Volume XXI & Nomor 1 & Maret 2020 & e-ISSN : 2580-9199 \\
\hline
\end{tabular}


Penelitian Cazalis \& Prévot, (2019) menentukan bahwa perilaku pro-lingkungan dipengaruhi oleh pengetahuan tentang lingkungan dan jarak antara tempat tinggal atau tempat kerja dengan daerah konservasi alam yang ada disekitarnya. Maka apabila DAS Citarum ditetapkan menjadi daerah konservasi alam, akan meningkatkan perilaku pro-lingkungan karyawan perusahaan, atau minimal pemerintah mengintensifkan program Citarum Harum harus terus dikampanyekan kepada perusahaan untuk mendorong tanggung jawab lingkungan perusahaan.

Penelitian Meloni, et.al., (2019) menjelaskan bahwa pandangan pembangunan berkelanjutan sangat mempengaruhi perilaku pro-lingkungan. Pembangunan berkelanjutan yang dimaksud adalah perilaku daur ulang, penghematan air, tidak membuang sampah sembarangan, transportasi ramah lingkungan serta dukungan lembaga pelestarian lingkungan sangat signifikan mempengaruhi perilaku pro-lingkungan. Dari 332 responden, hubungan antara pandangan tentang pembangunan berkelanjutan dan perilaku pro-lingkunan diperoleh nilai koefisien determinasi sebesar 0,20 yang artinya bahwa pandangan perilaku pro-lingkungan dipengaruhi oleh pandangan pembangunan berkelanjutan sebesar 20\%, sedang sisanya dipengaruhi oleh faktor lainnya.

\section{Hubungan antara Persepsi Ancaman} Ekologi $\left(\mathbf{X}_{2}\right)$ dengan Perilaku ProLingkungan (Y).

Dari uji regresi sederhana diperoleh persamaan $\hat{\mathrm{Y}}_{2}=0,442 \mathrm{X}_{2}+67,657$ dengan nilai korelasi $\left(\mathrm{r}_{\mathrm{y} 2}\right)$ sebesar 0,580 yang mengartikan bahwa terdapat hubungan signifikan antara variabel persepsi ancaman ekologi terhadap perilaku pro-lingkungan karyawan perusahaan (lihat Gambar 2). Besar nilai koefisien determinasi $\left(\mathrm{r}_{\mathrm{y} 2}{ }^{2}\right)=$ 0,337, hal tersebut menyimpulkan bahwa variabel tanggung jawab mempengaruhi sebesar $33,7 \%$ terhadap perilaku prolingkungan karyawan perusahaan, sedang sisanya berasal dari variabel yang tidak diteliti.

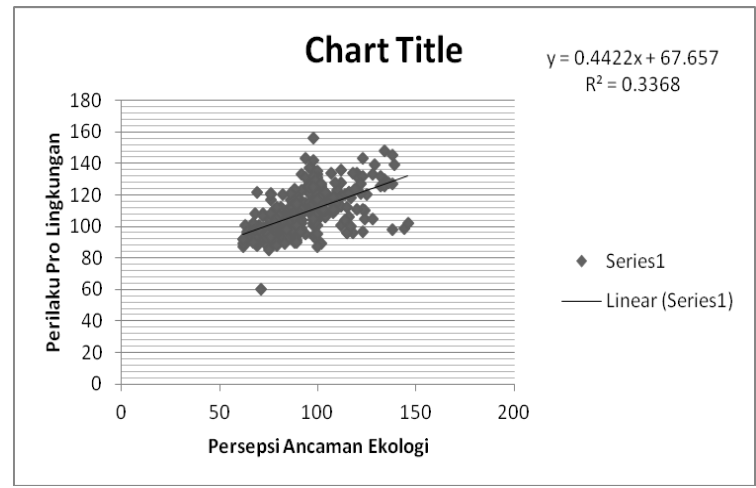

Gambar 2. Alur antara perilaku prolingkungan terhadap persepsi ancaman ekologi karyawan perusahaan

Penelitian Zhang \& Huang (2019), menjelaskan bahwa perilaku prolingkungan karyawan berhubungan dengan sikap lingkungan karyawan. Sikap lingkungan yang dimaksud adalah keinginan untuk meningkatkan perilaku pro-lingkungan karyawan perusahaan yang terkait dengan variabel autonomous motivation (AM) dan controlled motivation (CM) dari karyawan. Dalam penelitian ini, untuk mengukur persepsi ancaman ekologi menggunakan 5 indikator dengan nilai ratarata 54,09. Sehingga perlu dilaksanakan upaya untuk meningkatkan persepsi ancaman Ekologi bagi karyawan perusahaan.

Pada penelitian Cazalis \& Prévot, (2019) di jelaskan bahwa perilaku prolingkungan karyawan dipengaruhi oleh pengetahuan tentang lingkungan serta jarak tempat tinggal karyawan dengan daerah konservasi alam. Makin dekat tempat tinggal tersebut maka akan meningkatkan kesadaran karyawan tentang persepsi ancaman ekologi. Berdasarkan hasil penelitian ini, maka usaha untuk meningkatkan perilaku pro-lingkungan karyawan perusahaan dapat di stimulasikan

\begin{tabular}{|l|l|l|l|}
\hline Volume XXI & Nomor 1 & Maret 2020 & e-ISSN : 2580-9199 \\
\hline
\end{tabular}


dengan menetatapkan DAS Citarum sebagai kawasan konservasi, atau minimal pemerintah bersama Stake Holder terkait, mengkampanyekan dan menjalankan secara intensif program Citarum Harum yang sudah dijalankan.

3. Hubungan antara Tanggung Jawab Lingkungan $\left(\mathrm{X}_{1}\right)$ dan Persepsi Ancaman Lingkungan $\left(\mathrm{X}_{2}\right)$ secara Bersama-sama dengan Perilaku ProLingkungan Karyawan (Y)

Dari uji regresi sederhana diperoleh persamaan $\hat{\mathrm{Y}}_{12}=0,390 \mathrm{X}_{2}+0,063 \mathrm{X}_{1}+$ 66,063 dengan nilai korelasi $\left(r_{\mathrm{y} 2}\right)$ sebesar 0,585 yang mengartikan bahwa terdapat hubungan signifikan antara variabel persepsi ancaman Ekologi terhadap perilaku pro-lingkungan karyawan perusahaan. Besar nilai koefisien Determinasi $\left(\mathrm{r}_{\mathrm{y} 2}{ }^{2}\right)$ 0,343, hal tersebut menyimpulkan bahwa variabel tanggung jawab mempengaruhi sebesar $34,3 \%$ terhadap perilaku prolingkungan karyawan perusahaan, sedang sisanya berasal dari variabel yang tidak diteliti. Dapat disimpulkan bahwa secara bersama tanggung jawab lingkungan perusahaan dan persepsi ancaman Ekologi mempengaruhi lebih besar perilaku prolingkungan karyawan dibandingkan dengan berdiri sendiri-sendiri.

Penelitian Rivera \& Jua, (2010) menjelaskan bahwa perilaku prolingkungan sangat dipengaruhi oleh rasa tanggung jawab individu, pemahaman tentang kelestarian lingkungan dan kecerdasan dari individu itu sendiri. Ketiga unsur tersebut dapat di tumbuhkan melalui kesadaran pribadi, dan dapat di paksakan sesuai dengan kondisi sesuai lingkungannya. Kondisi dipaksakan yang dimaksud adalah dengan dibentuknya kebijakan-kebijakan atau aturan-aturan yang di rancang untuk memotivasi atau membentuk keyakinan setiap individu untuk memiliki kesadaran untuk menjaga kelestarian lingkungannya.

\section{KESIMPULAN DAN SARAN Kesimpulan}

Berdasarkan hasil dan pembahasan penelitian maka dapat ditarik kesimpulan dari penelitian ini sebagai berikut:

a. Terdapat hubungan positif yang signifikan antara tanggung jawab lingkungan perusahaan dengan perilaku pro-lingkungan karyawan perusahaan, dengan koefisien korelasi $\mathrm{r}_{\mathrm{y} .1}=0,448$ dan diperoleh persamaan regresi $\hat{\mathrm{Y}}_{1}=$ $0,275 \mathrm{X}_{1}+80,144$, berarti tanggung jawab lingkungan perusahaan dapat memprediksi secara signifikan terhadap perilaku pro-lingkungan karyawan perusahaan. Koefisien determinasi $\mathrm{r}_{\mathrm{y} 1}^{2}$ $=0,201$ yang berarti kontribusi tanggung jawab lingkungan perusahaan terhadap perilaku pro-lingkungan karyawan perusahaan sebesar 20,1\%, sedangkan sisanya dipengaruhi oleh faktor yang lain.

b. Terdapat hubungan positif yang signifikan antara persepsi ancaman ekologi dengan perilaku pro-lingkungan perusahaan, dengan koefisien korelasi sebesar $r_{\mathrm{y} .2}=0,580$ dan diperoleh sebuah persamaan regresi $\hat{Y}_{2}=$ $0,442 X_{2}+67,657$ berarti persepsi ancaman ekologi dapat memprediksi secara signifikan terhadap perilaku prolingkungan karyawan perusahaan. Sedangkan koefisien determinasi $\mathrm{r}_{\mathrm{y} 2}^{2}=$ 0,337 , yang berarti kontribusi persepsi ancaman ekologi terhadap perilaku prolingkungan karyawan perusahaan sebesar 33,7\%, sedangkan sisanya dipengaruhi oleh faktor yang lain.

c. Terdapat hubungan positif yang signifikan antara pengetahuan tanggung jawab lingkungan perusahaan dan persepsi ancaman ekologi secara bersama-sama dengan perilaku prolingkungan karyawan perusahaan, dengan koefisien korelasi $\mathrm{r}_{\mathrm{y} .12}=0,585$ dan diperoleh persamaan regresi $\hat{\mathrm{Y}}_{12}=$ $0,063 X_{1}+0,390 X_{2}+66,063$. Dari hasil perhitungan diperoleh hasil 
koefisien determinasi sebesar $\mathrm{r}_{\mathrm{y} .}{ }^{2}{ }_{12}=$ 0,343 yang berarti kontribusi tanggung jawab lingkungan perusahaan dan persepsi ancaman ekologi terhadap perilaku pro-lingkungan karyawan perusahaan sebesar 34,3\% dan sisanya dipengaruhi oleh faktor yang lain.

\section{SARAN}

\section{a. Pemerintah.}

1) Membuat kebijakan berupa peraturan daerah yang memaksa setiap perusahaan untuk membuat kegiatan pelestarian lingkungan sekitar perusahaan.

2) Mengontrol dan mengevaluasi secara langsung pelaksanaan program atau kegiatan pelestari-an lingkungan yang dilaksanakan perusahaan.

3) Memberikan peringatan atau tindakan hukum nyata kepada perusahaan yang tidak melaksanakan kegiatan pelestarian lingkungan sekitar perusahaannya.

4) Guna mengembalikan nilai guna DAS Citarum maka peme-rintah sebaiknya menjadikan wilayah DAS Citarum sebagai kawasan konservasi alam yang harus dilindungi dan di awasi.

\section{b. Perusahaan.}

1) Perusahaan tempat karyawan bekerja harus secara aktif mengkampanyekan kegiatan pelestarian lingkungan yang dilaksanakan, dan melibatkan secara langsung karyawannya dalam kegiatan tersebut.

2) Perusahaan harus memberi-kan pemahaman tentang hayati dan persepsi ancaman ekologi, sehingga dapat meningkatkan perilaku prolingkungan dari karyawannya.
3) Perusahaan harus merencanakan, melaksanakan dan mengevaluasi program manajemen hijau dan kontrol manajemen dalam rangka menjaga menjamin kelestarian lingkungan perusahaannya.

\section{c. Karyawan.}

1) Meningkatkan perilaku prolingkungan dengan jalan mendukung pelaksanaan program pembangungan berkelanjutan yang ditetapkan perusahaan.

2) Meningkatkan kerelaan dan keikhlasan dalam menjalankan perilaku pro-lingkungan agar terjamin kelesatarian lingkungan.

\section{REFERENSI}

Cazalis, V., \& Prévot, A. (2019). Are protected areas effective in conserving human connection with nature and enhancing proenvironmental behaviours? Biological Conservation, (December 2018), 1-8. https://doi.org/10.1016/j.biocon.2 019.03.0

Holtbrügge, D., \& Dögl, C. (2012). How international is corporate environmental responsibility? A literature review. Journal of International Management, 18(2), 180-195.

https://doi.org/10.1016/j.intman.20 12.02.001.

Macintyre, A., Torgler, B., \& García-vali, M. A. (2012). Volunteering, proenvironmental attitudes and norms, 41, 455-467. https://doi.org/10.1016/j.socec.201 $\underline{1.07 .001}$.

Meloni, A., Fornara, F., \& Carrus, G. (2019). Predicting proenvironmental behaviors in the 
urban context: The direct or moderated e ff ect of urban stress, city identity, and worldviews. Cities, 88(December 2018), 83-90. https://doi.org/10.1016/j.cities.2019. 01.001

Mukherjee, A., Bird, R., \& Duppati, G. (2018). Mandatory Corporate Social Responsibility: The Indian Experience Abhishek Mukherjee * Ron Bird **, $\uparrow$ Geeta Duppati ** Freedom Institute of Higher Education ** Finance Discipline , Waikato School of Management $\dagger$ Director , IMR Program , University of Tech. Journal of Contemporary Accounting \& Economics.

https://doi.org/10.1016/j.jcae.2018. 06.002 .

Pothitou, M., Hanna, R. F., \& Chalvatzis, K. J. (2016). Environmental knowledge , pro-environmental behaviour and energy savings in households: An empirical study. Applied Energy. https://doi.org/10.1016/j.apenergy.2 016.06.017

Rivera-martı, J. G., \& Jua, M. (2010). An explorative socio-psychological model for determining sustainable behavior: Pilot study in German and Mexican Universities, 18, 686694.

https://doi.org/10.1016/j.jclepro.200 9.09.018

Ruepert A, M., Keizer K., \& Steg L., 2017, The Relationship between Corporate Environment Responsibility, employeees biospheric values and proenvironmental behaviour at work. Journa of Environmental Psychology, 54: 65-78, DOI. Org/10.1016/j.jenvp, 2017. 10.006
Saputro, Y , 2018, Misi besar mengatasi pencemaran sungai Citarum, www. Rapplew. Com. Di akses bulan Januari 2018.

Schmitt, M. T., Aknin, L. B., Axsen, J., \& Shwom, R. L. (2018). Unpacking the Relationships Between Proenvironmental Behavior , Life Satisfaction , and Perceived Ecological Threat $\begin{gathered}\text { ? } \\ \text {. Ecological }\end{gathered}$ Economics, 143, 130-140. https://doi.org/10.1016/j.ecolecon. 2017.07.007.

Tkalac, A., \& Sin, D. (2018). The relationship between reputation, employer branding and corporate social responsibility, (March). https://doi.org/10.1016/j.pubrev.201 8.06.005

Truelove, H. B., \& Gillis, A. J. (2018). Perception of pro-environmental behavior. Global Environmental Change, 49(February), 175-185. https://doi.org/10.1016/j.gloenvcha .2018.02.009.

Yanes, A., Botero, C. M., Arrizabalaga, M., \& Guillermo, J. (2017). Methodological proposal for ecological risk assessment of the coastal zone of. Ecological Engineering, (December), 0-1. https://doi.org/10.1016/j.ecoleng.2 017.12.010.

Zhang, J., \& Huang, R. (2019). Journal of Hospitality and Tourism Management Employees , proenvironmental behaviours ( PEBs ) at international hotel chains ( IHCs ) in China: The mediating role of environmental concerns ( ECs ). Journal of Hospitality and Tourism Management, 39(June 2018), 129136.

https://doi.org/10.1016/j.jhtm.2019. 
03.007 